\title{
Um jornalista em Incidente em Antares e outros que também escrevem
}

Deonisio da Silva*

\section{Un periodista en Incidente en Antares y otros que también escriben A journalist in Incident in Antares and others that also write}

Incidente em Antares é, para mim, escritor e professot de Letras, uma aula de romance, uma lição de como se tece uma narrativa, de como podem ser organizadas as tramas, perfilados os personagens e exposto, em tantas sutis complexidades, o oficio de quem escreve.

$\mathrm{Na}$ leitura que ora faço do imaginoso romance, fixei-me em figuras que exemplificam a arte de narrar, a começar pelo onisciente narrador do romance, mas também por suas encarnaçōes, como o jornalista Lucas Faia, cujo relato do incidente, aliás, jamais vem a ser publicado, exatamente porque foi censurado, espelhando a dura realidade da censura nos conturbados anos setenta, quando a Editora Globo lançou aquele que seria o último romance do escritor.

Três momentos decisivos estruturam uma narrativa: a abertura, o desenvolvimento das tramas e o fechamento. No caso de Incidente em Antares, impressiona a competência com que o escritor, em meias palavras, ainda no primeiro capítulo, anuncia o que vai contar, onde e quando se deu o incidente, fazendo estrear o jornalista Lucas Faia (o nome de seu jornal é A Verdade) e o padre Geroncio (ah, o poder do padre nas pequenas e antigas comunidades rurais, encarregado de outras verdades), duas personagens de relevo na pequena cidade cuja existência cartógrafos não reconhecem nos mapas que fazem, o que leva o prefeito municipal, os vereadores e outras figuras gradas de Antares a enviar repetidos memoriais ao Instituto Histórico e Geográfico do Rio Grande do Sul e ao IBGE, protestando contra a omissão, "como se São Borja fosse a única localidade digna de nota naquelas paragens do Alto Uruguai".

Quanto à exclamação do padre, gritando dentro da igreja, que tinha começado em sua paróquia o Juízo Final, o contraponto é dado pela ironia, recurso contumaz na ficção do autor, cujo pequeno véu é levantado - ironia nāo é revelar o avesso das coisas? - na precisa intervenção de um gaiato, "desses que costumam menosprezar a terra onde nasceram e vivem" (não era esta a principal acusaçåo da ditadura militar contra os intelectuais críticos do período, conclamados a amar ou deixar o país?): "a troco de quê Deus havia de começar o Juízo Final logo neste cafundó onde Judas perdeu as botas?" (p.2).



Mas a existência da Antares que o escritor criou é atestada logo no segundo parágrafo do primeiro capítulo: "no entanto a verdade clara e pura é que, a despeito da má vontade ou da ignorância dos fazedores de cartas geográficas, a cidade de Antares, sede do município de mesmo nome, lá está, visível e concreta, à margem esquerda do grande rio". (p.2) Ou por outra: quem lhe garante a existência é o poder do escritor que a criou com sua palavra, nenhum outro, fazendo fulgurar na ficçāo a realidade que o documental ignora e omite. $O$ narrador não perde de vista o tema solar de sua narrativa, o incidente, e vai do pleistoceno ao século XIX, onde situará a origem dos célebres conflitos cuja liquidação ocorrerá no século seguinte, em apenas trếs páginas.

Como que ensinando a quem escreve como deve proceder, o narrador desvela seu método, ao sustar os desdobramentos do incidente anunciado, "de que Antares foi teatro na sexta-feira 13 de dezembro de 1963 ", e que a tornou subitamente conhecida no "Rio Grande do Sul, no resto do Brasil e em todo o mundo civilizado" (po.2), ainda que nem isso tenha sensibilizado geógrafos e cartógrafos.

Isto é, Antares é criada apenas como palco para que ali possam ser desenrolados os eventos. E o narrador assegura seu método, presente, aliás, em outros romances do autor, que consiste primeiramente em fixar o contexto da história que vai contar: "não convém antecipar fatos nem ditos", pois "meIhor será contar primeiro, de maneira tão sucinta e imparcial quanto possível, a história de Antares e de seus habitantes, para que se possa ter uma idéia mais clara do palco, do cenário e principalmente das personagens principais, bem como da comparsaria, desse drama talvez inédito nos anais da espécie humana". (p.2)

Como se vê, está delineado "o método Erico Verissimo" de construir seu romance. Vamos agora aos destaques que escothi para esta leitura. O primeiro é o naturalista francês Gaston Gontran d'Auberville, que registra em seu diário, que cobre a viagem que teria feito entre 1831 e 1832, ter encontrado Francisco Vacariano. Este the mostra o que os índios chamam "flauta do sol", uma garça que saúda o sol nascente com um "assobio proIongado, duma suavidade indescritível, a um tempo bucólico e triste, lembrando o pífaro de um pastor" (p.6). E é num diálogo com esse ancestral de Tibério Vacariano, que cumprirá função decisiva no conflito entre os Vacariano e os Campolargo, que surgirá a explicação para o nome da localidade. Apontando a Antares em noite estrelada, o naturalista acede ao pedido do anfitriāo que o acolheu e escreve o nome num pedaço de papel, ouvindo entretanto: "mas nāo acredito que essa estrela seja mesmo maior que o Sol". (p.6). De todo modo, é de sua pena que surge o nome que vai substituir a denominaçāo infeliz de Povinho da Caveira, nome original da localidade. 
Outro registro que reforça o papel decisivo de quem escreve é mais documentado inventado. Desta vez substitui o naturalista francês um religioso argentino, o Pe. Juan Bautista Otero, que escreve uma carta a seu provincial, em Buenos Aires, em 4 de dezembro de 1832 , depois de obter "permissāo do dono daquelas terras, um certo Sr. Francisco Bacariano (sic) para fazer casamentos e batizados: "O Sr. Bacariano não me parece ter muito respeito pela nossa religiāo ou por qualquer outra" (p.7). O mesmo padre que registra que Francisco Bacariano casará com Angélica, filha de um abastado estancieiro de Alegrete.

Pouco a pouco, o narrador conduzirá o leitor ao inferno de Antares, evitando que se perca na selva escura das origens que entretanto é preciso aclarar, pois datam a gênese das "duas grandes oligarquias que em Antares, durante cerca de setenta anos, disputaram o predomínio político, social e econômico" (p.24). A paz entre as duas oligarquias, obra de Getúlio Vargas, é celebrada com um diálogo que interrompe um silêncio de sessenta anos entre os Campolargo e os Vacariano. Cada um deles pergunta pela "patroa" do outro, um deles ignorando que o desafeto é viúvo há mais de um ano.

Mas por que tal escolha narrativa? "Ficaram assim na penumbra do segundo, do terceiro e do último plano todos aqueles que - para usar duma expressão de Splenger - nāo "fazem" mas "sofrem" a História, a saber; estancieiros menores, agricultores de minifúndios, membros das profissōes liberais e do magistério e ministério públicos, funcionários do governo, comerciantes, artesãos e por fim essa massamorda humana composta de párias - brancos, caboclos, mulatos, pretos, curiobas, mamelucos - gente sem profissão certa, changadores, índios vagos, mendigos, "gentinha" molambenta e descalça, que vivia num plano mais vegetal ou animal do que humano, e cuja situação era em geral aceita pelos privilegiados como parte duma ordem natural, dum ato divino irrevogável". (p.24)

Quanto aos outros, os "homens de bem e de paz", cuja inexistência em Antares o narrador imagina natural que o leitor estranhe, diz: "desgraçadamente seus ditos, feitos e gestos não foram recolhidos pela história oficial", acrescentando que "apenas poucos deles incorporaram-se à tradiçăo oral da cidade e do município: os restantes perderam-se para sempre no olvido", (p,24).

Depois de rapidamente aludir ao primeiro poeta de Antares, um jovem dos Campolargo, definido simplesmente como "fresco" por Xisto Vacariano, entra em cena mais um profissional das letras. É Mário Pinho, tipógrafo, o primeiro comunista de Antares, que ali vive quando corre o ano de 1925 já. As referências a quem escreve não param aí, pois também as pesquisas financiadas pela Fundação Ford, de responsabilidade do professor Martim Francisco, vền a lume sob o título Anatomia de uma Cidade. Os pesquisadores que visitaram Antares sāo chamados "gafanhotos" e ganham a repulsa dos poderes locais. Até um comunista, observando a agência financiadora, acha que só pode ser coisa da CIA. Penando para ser publicado, o livro, quando vem à luz, em 1962, causa furor em Antares, mesmo que ali tenham chegado apenas três exemplares.

Um trecho exemplifica o estilo que tanto incomodou as lideranças locais, embora Antares apareça disfarçada sob o nome de Ribeira: "O Rio Grande do Sul é o Estado mais reacionário do Brasil, e Ribeira a cidade mais reacionária do Rio Grande do Sul (...) Veneramos morbidamente um passado e uma tradiçāo já mortos, se é que de fato um dia existiram mesmo, e somos incapazes de sair dos trilhos da rotina e erguer a cara para o sol do futuro". E o depoimento é feito por "um jovem estudante, filho de tradicional família do município". (p.140).
Convido os leitores, porém, a examinar a figura mais importante para os propósitos desta leitura: o jornalista Lucas Faia. Ele é o grande personagem do segmento que escolhi, com o fim de realçar o valor que Erico Verissimo dá a quem escreve em Incidente em Artares. Parecem-nos muito familiares os textos do jornalista Lucas Faia, que é jornalista na mesma medida em que Tibério Vacariano é coronel - um, sem freqüentar curso superior que o titulasse; outro, sem jamais entrar num quartel, nem como recruta, ainda assim sendo de fato, um, jornalista; outro, militar que está presente em todos os rincōes do Brasil, infestando com o seu estilo pomposo os pequenos jornais, quando não submissos ao poder local, inapelavelmente empastelados ou censurados.

Eis amostra do incidente na pena do barroco Lucas Faia: "foi numa última sexta-feira 13 deste cálido e, já agora, trágico dezembro. $\mathrm{O}$ dia amanheceu luminoso, de céu limpo e translúcido, e a nossa cidade, o rio e as campinas em derredor semelhavam o interior duma imensa catedral plateresca, toda laminada pelo ouro dum sol que mais parecia um ostensório suspenso no altar do firmamento. (...) Tudo parecia em paz no mundo. Era mais um dia na vida de Antares - pensavam decerto os que despertavam para a faina cotidiana. Mas ai! Mal sabiam eles do álgido horror que os esperaval (...) A brônzea voz do sino da nossa Matriz chamava os fiéis para a missa das sete quando os sete mortos, em sinistra formatura, desceram sobre a cidade, ao longo da popular Rua Voluntários da Pátria, semeando o susto, o pavor e o pânico. Pareciam - segundo o depoimento de várias pessoas idôneas ouvidas pelo nosso repórter - figuras egressas dum grotesco museu de cera". (p.259).

Mas como a mostrar que há outros modos de escrever, além do demonstrado com a enxuta narrativa do romance, surgem os versos de Mário Quintana, recitados por "uma senhora de boas letras": "e os sinos dançam no ar./ De casa casa, os beirais / - Para lá e para cá - / Trocam recados de asas,/ Riscando sustos no ar/ Silêncio. Sinos. Apelos. Sinos./ E sinos. Sinos. E sinos. Sinos./ Pregoeiros. Sinos. Risadas. Sinos./ E levada pelos sinos,/ Toda ventando de sinos,/ Dança a cidade no ar". (p.448).

A metáfora é mais do que apropriada. O sino foi o primeiro jornal das pequenas localidades! E em algumas ainda é o único!

$O$ jornalista Lucas Faia é personagem relevante em Incidente em Antares.

Seu jornal A Verdade jamais acolheria o tom objetivo dos que escrevem de modo diferente, cobrindo o mesmo incidente, no Correio do Povo, no Diario de Notícias, na Folha da Tarde e na Ultima Hora, todos citados no romance. Não terá tampouco o diploma de jornalista o repórter que acompanha o cinegrafista da Rádio e Televisão Gaúcha na cobertura do incidente. Desembarcando dos automóveis que os trouxeram de Porto Alegre, perguntam objetivamente ao primeiro que encontram: "onde estāo os defuntos?". (p.449). E ouvem a mais objetiva das respostas: "no cemitério". (p.449).

Ainda assim, o incidente é noticiado no Ashashi Sinbum, na revista Time, no Le Monde, no Times. Como? "Por artes do repórter da barbicha quixotesca, os correspondentes das agências de notícias UPI, AP e France Presse transmitiram aos jornais do mundo notícias sobre o estranho incidente de Antares" (p.465),

Em A Verdade, porém, Lucas Faia nào conseguiu publicar uma só linha de sua reportagem. Lida em voz alta aos próceres locais, é vetada no primeiro ato do que chamaram Operaçāo Borracha, metáfora da censura que asfixiava o país ao tempo do incidente.

Entretanto, a luta de Lucas Faia continuará por outros meios. No desfecho do romance, surge um menino de sete anos, 
filho de um modesto funcionário público, que "para mostrar aos circunstantes que já sabia ler", começa a soletrar uma palavra de piche, desenhada por estudante que morrera alvejado pela polícia, tendo seu sangue desenhado na calçada, segundo a imaginação popular, a configuraçẩo do Brasil: "Li-ber...".

O último diálogo exemplifica o clima dominante quando Incidente em Antares foi publicado: " - Cala a boca, bobalhão! exclamou o pai, quase em pânico. E, puxando com força a mão do filho, levou-o, quase de arrasto, rua abaixo". (p.485).

Fiel a seu ideal libertário, mais uma vez Érico Veríssimo riscava um fósforo na escuridão daqueles anos, lembrando aos que, como eu, queriam ser escritores, uma das grandes missōes de quem escreve: defender a liberdade. Com efeito, as ameaças vêm às vezes de onde menos esperamos, sendo nossas ligaçóes com o sociedade epocal sempre muito perigosas. Quem escreve, mexe no coração da sociedade. E isso Lucas Faia, censurado pelo poder local, e o menino, que leva um safanăo do pai ao tentar soletrar a palavra "liberdade", interrompida com tiro mortal no muro onde um estudante tentou afixá-la em grandes letras, experimentaram, como tantos de nós, os rigores das interdiçōes que buscam controlar quem escreve.

Érico Veríssimo deu-nos sublime lição. Não se submeteu a nenhuma das duas forças que disputavam a hegemonia no mundo e no Brasil. Foi fiel à liberdade de escrever o que queria, como queria, arrostando todas as consequiências de tal atitude, a começar pelo desprezo pernóstico dos círculos tidos por elegantes nas universidades e na inteligência epocal.

Teve grande aliado em seu projeto literário, o mais importante, o decisivo na vida de todo escritor; o leitor. (xx). 